\title{
Persistence of upper stratospheric wintertime tracer variability into the Arctic spring and summer
}

\author{
David E. Siskind ${ }^{1}$, Gerald E. Nedoluha ${ }^{2}$, Fabrizio Sassi ${ }^{1}$, Pingping Rong ${ }^{3}$, Scott M. Bailey ${ }^{4}$, Mark E. Hervig ${ }^{5}$, and \\ Cora E. Randall ${ }^{6}$ \\ ${ }^{1}$ Space Science Division, Naval Research Laboratory, Washington DC, USA \\ ${ }^{2}$ Remote Sensing Division, Naval Research Laboratory, Washington DC, USA \\ ${ }^{3}$ Center for Atmospheric Sciences, Hampton University, Hampton, VA, USA \\ ${ }^{4}$ Bradley Department of Electrical and Computer Engineering, Virginia Tech, Blacksburg, VA, USA \\ ${ }^{5}$ GATS-Inc., Driggs, ID, USA \\ ${ }^{6}$ Laboratory of Atmospheric and Space Physics and Department of Atmospheric and Oceanic Sciences, \\ University of Colorado, Boulder CO, USA
}

Correspondence to: David Siskind (david.siskind@nrl.navy.mil)

Received: 21 December 2015 - Published in Atmos. Chem. Phys. Discuss.: 29 January 2016

Revised: 12 May 2016 - Accepted: 30 May 2016 - Published: 30 June 2016

\begin{abstract}
Using data from the Aeronomy of Ice in the Mesosphere (AIM) and Aura satellites, we have categorized the interannual variability of winter- and springtime upper stratospheric methane $\left(\mathrm{CH}_{4}\right)$. We further show the effects of this variability on the chemistry of the upper stratosphere throughout the following summer. Years with strong wintertime mesospheric descent followed by dynamically quiet springs, such as 2009, lead to the lowest summertime $\mathrm{CH}_{4}$. Years with relatively weak wintertime descent, but strong springtime planetary wave activity, such as 2011, have the highest summertime $\mathrm{CH}_{4}$. By sampling the Aura Microwave Limb Sounder (MLS) according to the occultation pattern of the AIM Solar Occultation for Ice Experiment (SOFIE), we show that summertime upper stratospheric chlorine monoxide $(\mathrm{ClO})$ almost perfectly anticorrelates with the $\mathrm{CH}_{4}$. This is consistent with the reaction of atomic chlorine with $\mathrm{CH}_{4}$ to form the reservoir species, hydrochloric acid $(\mathrm{HCl})$. The summertime $\mathrm{ClO}$ for years with strong, uninterrupted mesospheric descent is about $50 \%$ greater than in years with strong horizontal transport and mixing of high $\mathrm{CH}_{4}$ air from lower latitudes. Small, but persistent effects on ozone are also seen such that between 1 and $2 \mathrm{hPa}$, ozone is about $4-5 \%$ higher in summer for the years with the highest $\mathrm{CH}_{4}$ relative to the lowest. This is consistent with the role of the chlorine catalytic cycle on ozone. These dependencies may offer a means to monitor dynamical effects on the high-latitude
\end{abstract}

upper stratosphere using summertime $\mathrm{ClO}$ measurements as a proxy. Additionally, these chlorine-controlled ozone decreases, which are seen to maximize after years with strong uninterrupted wintertime descent, represent a new mechanism by which mesospheric descent can affect polar ozone. Finally, given that the effects on ozone appear to persist much of the rest of the year, the consideration of winter/spring dynamical variability may also be relevant in studies of ozone trends.

\section{Introduction}

There has recently been great interest in the variability of middle atmospheric trace constituents at high latitudes in the late winter and early spring. This interest has been fueled, in part, by the occurrence of prolonged sudden stratospheric warmings (SSWs) which can perturb the composition and structure of the stratosphere and mesosphere for many weeks (Manney et al., 2008a, b, 2009). These so-called extended SSWs are characterized by elevated stratopauses which reform near and above $80 \mathrm{~km}$ (Siskind et al., 2007; Manney et al., 2009). During the recovery phase of these extended events, the anomalous zonal wind flow alters the gravity wave propagation to the mesosphere, thus perturbing the mean meridional circulation and driving a dramatic de- 
scent of mesospheric air down to the stratosphere (Siskind et al., 2010; Chandran et al., 2013). For example, (Bailey et al., 2014) have shown that mesospheric air enhanced in nitric oxide (NO) and depleted in water vapor $\left(\mathrm{H}_{2} \mathrm{O}\right)$ and methane $\left(\mathrm{CH}_{4}\right)$ can descend from near $90 \mathrm{~km}$ in early February down to $40 \mathrm{~km}$ by early April. Bailey et al. (2014) focused on the 2013 SSW; other analogous events occurred in 2004, 2006 and 2009 (Manney et al., 2005, 2009; Randall et al., 2009). An additional motivation for most of the above studies is the interest in quantifying the extent to which the enhanced nitric oxide can cause reductions in polar upper stratospheric ozone (Funke et al., 2014).

There has been less attention paid to what happens to these dramatic perturbations as the spring progresses and the wintertime circulation transitions into a summer pattern. It has long been recognized that the winter to spring transition is characterized by a decay and breakdown of the wintertime westerly jet and its eventual replacement by a zonal mean easterly flow around the polar region. This is known as the stratospheric final warming (SFW) (Hu et al., 2014). It has been observed that certain remnants of wintertime dynamical (Hess, 1990) or chemical tracer features (Orsolini, 2001; Lahoz et al., 2007) can persist well into the summer season. Most recently, work has focused upon specific events, whereby the SFW can occur rather abruptly with a significant late season planetary wave event (Allen al., 2011; Siskind et al., 2015a; Fiedler et al., 2014). These planetary waves can transport low-latitude anticyclonic air poleward. This air can displace the winter polar vortex and then remain "frozen in" for a period of weeks or longer in late spring and early summer (Manney et al., 2006). Alternatively, this transition can occur gradually without significant wave activity. In the former case, the upper mesosphere often experiences cooler and wetter conditions which can lead to the early onset of the polar mesospheric cloud season. In the latter case, the upper mesosphere remains warmer and drier. Siskind et al. (2015a) showed that 2011 and 2013 were years with an abrupt winter to spring transition and 2008 was a spring with negligible planetary wave activity. They used these years to define the extremes in springtime planetary wave activity and associated temperatures.

From the above, we can define four general scenarios for the transition from winter to summer based upon the combination of the two perturbations outlined above. We can have a year with extended descent of mesospheric air (typically the result of a extended SSW) or a winter with weak descent. These winters can be followed by springs with either an abrupt planetary wave transition to a summer circulation or with a slower gradual transition. The purpose of this paper is to categorize the four possible combinations of these springtime scenarios and how they are manifested in the variability of trace constituents such as $\mathrm{CH}_{4}$, chlorine monoxide $(\mathrm{ClO})$ and ozone $\left(\mathrm{O}_{3}\right)$. Among our results, we will show that under certain circumstances, the zonal mean distribution of these trace constituents can be perturbed for many months even into the autumn. This is important because while the summer upper stratosphere is generally understood to be under radiative and photochemical control (Andrews et al., 1987), we will show how the zonal mean composition can be sensitive to dynamical changes that might have occurred over half a year prior.

\section{Observations and model}

\subsection{SOFIE and MLS data}

Our primary data come from the Solar Occultation for Ice Experiment (SOFIE) (Gordley et al., 2009) on the Aeronomy of Ice in the Mesosphere (AIM) satellite (Russell III et al., 2009) and the Microwave Limb Sounder (MLS) (Santee et al., 2008; Froidevaux et al., 2008) on the Aura satellite (Waters, 2006). SOFIE measures profiles of temperature, aerosols (ice and meteoric smoke) and $\mathrm{O}_{3}, \mathrm{H}_{2} \mathrm{O}, \mathrm{CO}_{2}, \mathrm{CH}_{4}$ and $\mathrm{NO}$ using the solar occultation technique. Since the AIM satellite is in a sun-synchronous polar orbit, the latitude of the occultations approximately tracks the terminator and is above $82^{\circ}$ near equinox and near $65^{\circ}$ at solstices. SOFIE acquires approximately 15 samples day ${ }^{-1}$, uniformly spaced in longitude. The vertical resolution is about $2 \mathrm{~km}$. Gordley et al. (2009) quote a precision for the $\mathrm{CH}_{4}$ data of $10 \mathrm{ppbv}$ at $70 \mathrm{~km}$. This work uses version 1.3 SOFIE data. SOFIE $\mathrm{CH}_{4}$ data have previously been presented by Bailey et al. (2014) and (Siskind et al., 2015b) and were shown to vary in a manner consistent with the other tracers of mesospheric descent measured by SOFIE; ongoing validation studies (Rong et al., 2016) with the Atmospheric Chemistry Experiment suggest general agreement to within approximately $12 \%$. Here we emphasize the relative year to year variations.

Like AIM, the Aura satellite is also in a sun-synchronous orbit. However, unlike SOFIE, because MLS observes $\mathrm{ClO}$ and $\mathrm{O}_{3}$ in emission, data are obtained over all latitudes up to about $82^{\circ} \mathrm{N}$. We used Version 4.2 data. The MLS ozone was validated by (Froidevaux et al., 2008) and used in a study of lower mesospheric photochemistry by Siskind et al. (2013). The ClO data have been validated by (Santee et al., 2008) and compared with ground-based data by (Nedoluha et al., 2011). Santee et al. (2008) show that the precision of the MLS ClO decreases for pressures less than $2 \mathrm{hPa}$; however, since we only show monthly averages, this is not a problem for the present study. It is also common practice to subtract the nighttime data from the daytime data (Santee et al., 2008; Nedoluha et al., 20011) in order to reduce systematic biases; however, for the high-latitude spring/summer conditions shown here, there are often no night periods. Thus a given monthly average was constructed using data from all local times without any background subtraction. The vertical resolution of the MLS ClO observation (3-4 km) is somewhat coarser than SOFIE. We thus interpolated the SOFIE profile to the MLS grid. 

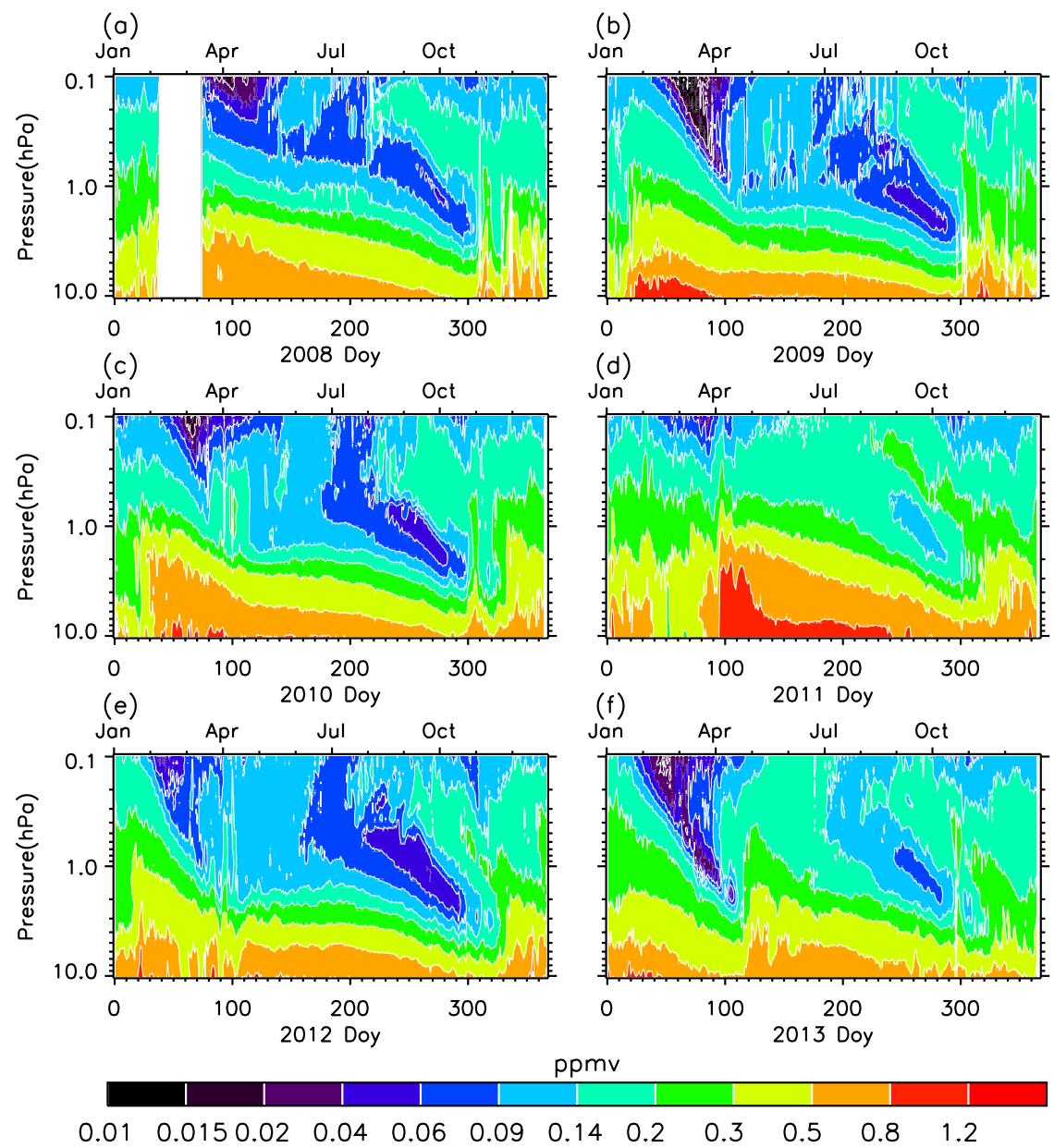

Figure 1. Overview of upper stratospheric and lower mesospheric zonal mean $\mathrm{CH}_{4}$ observed by SOFIE for the indicated years. SOFIE observes at only one latitude per day in each hemisphere. This latitude has some variation from year to year, but is typically near $82^{\circ}$ at the equinoxes and near $65-66^{\circ}$ at the solstices. The horizontal axis label, doy, is day of year.

\subsection{The Whole Atmosphere Community Climate Model (WACCM)}

We also compare some of our results with WACCM (Garcia et al., 2007). WACCM is the high-altitude atmospheric component of the NCAR Community Earth System Model version 1 (CESM1). In its standard configuration, WACCM has 66 vertical levels from the ground to about $5.9 \times 10^{-6} \mathrm{hPa}$ (approximately $140 \mathrm{~km}$ geometric height) and a horizontal resolution of $1.9^{\circ}$ latitude $\times 2.5^{\circ}$ longitude. See Garcia et al. (2007) for a detailed discussion of the model climatology and parameterizations. This version of WACCM uses specified dynamics provided by the Navy Operational Global Atmospheric Prediction System - Advanced Level Physics High Altitude (NOGAPS-ALPHA) (Marsh, 2011; Sassi et al., 2013). NOGAPS-ALPHA is the high-altitude extension of the then operational Navy's weather forecast system up to about 90-92 km (Eckermann et al., 2009). Siskind et al. (2015b) have already shown that the combina- tion of WACCM and NOGAPS-ALPHA (hereinafter called WACCM/NOGAPS) produced a successful representation of the descent of enhanced upper mesospheric and lower thermospheric nitric oxide (NO) and depleted $\mathrm{CH}_{4}$ into the upper stratosphere/lower mesosphere. By contrast, WACCM nudged only up to $50-60 \mathrm{~km}$ by the Modern Era Retrospective Analysis for Research and Applications (MERRA) dataset did not (see also Randall et al., 2015). Since mesospheric descent is so important for understanding our present results, we only use WACCM/NOGAPS for this study. Unfortunately, of the 7 years considered here (2008-2014), WACCM/NOGAPS is only available for the first 2 . We thus can not use it to reproduce all the variability seen in the SOFIE data. However, by comparing summer results from 2009 with 2008, we can provide a broader context to the latitudinal extent of the $\mathrm{CH}_{4}$ changes and their effect on the chlorine and ozone chemistry of the upper stratosphere. 


\section{Results}

\subsection{Methane $\left(\mathrm{CH}_{4}\right)$}

Our specific interest is to highlight the consequences of the variations in upper stratospheric $\mathrm{CH}_{4}$ as observed by SOFIE and shown in Figs. 1 and 2. These figures illustrate the great variability that occurs in $\mathrm{CH}_{4}$ each winter and spring. Figure 1 , which presents 6 years of SOFIE $\mathrm{CH}_{4}$, shows that each year is characterized by the descent of low values of $\mathrm{CH}_{4}$ from the mesosphere in the period from February to early April (roughly day 30 to day 110). This descent is characterized by large interannual variability and was strongest in 2009 and 2013. These were years with prolonged SSWs followed by elevated stratopauses and have been covered in the literature (Manney et al., 2009; Randall et al., 2009; Bailey et al., 2014). The difference between 2009 and 2013 is that in 2013, there was a large frozen-in anticyclone event (FrIAC; Manney et al., 2006) that transported air with high values of $\mathrm{CH}_{4}$ to high latitudes (Siskind et al., 2015a), whereas in 2009, no such springtime disturbance was evident. This is clearly seen in Fig. 2 where the $\mathrm{CH}_{4}$ jumps from below $0.1 \mathrm{ppmv}$ on day 100 to over 0.3 ppmv by day 120 . Years with a more moderate and shorter period of winter/early spring descent are 2010 and 2012. These 2 years did not have elevated stratopause events as in 2009 and 2013, but there were wintertime SSWs in both years, and Straub et al. (2012) discussed the descent of dry air at high latitudes in the lower mesosphere during the late winter of 2010. The springtime vortex breakdown occurred relatively gradually over many weeks in March and April for both 2010 and 2012, and thus there was no transport of high $\mathrm{CH}_{4}$ in either spring. These years ended up being close to 2009 in having low values of $\mathrm{CH}_{4}$ persist into the summer. Even less mesospheric descent was seen in 2008 and the least descent was seen in 2011. The year 2011 was characterized by a strong undisturbed stratospheric polar vortex (Manney et al., 2011). Then, in early April (Day 95) of that year, the largest FrIAC of the 36-year MERRA dataset was recorded (Allen et al., 2011; Thieblemont et al., 2013), causing a significant jump in upper stratospheric $\mathrm{CH}_{4}$.

After the spring, there is a second period of decreasing $\mathrm{CH}_{4}$ in the summer (most noticeable after day 200). This summertime decrease is due to photochemistry (Funke et al., 2014), as the production of $\mathrm{O}\left({ }^{1} \mathrm{D}\right)$ and $\mathrm{OH}$, both of which oxidize $\mathrm{CH}_{4}$, peak at high summer latitudes in the upper stratosphere (Letexier et al., 1988). Since the upper stratosphere at this time of year is dynamically quiet, the year to year variability in summer $\mathrm{CH}_{4}$ is driven by the winter- and springtime dynamics. This can be seen in Fig. 2a, which compares time series of upper stratospheric $\mathrm{CH}_{4}$ for the 6 years shown in Fig. 1 plus 2014. The figure shows that the lowest summer $\mathrm{CH}_{4}$ was generally in 2009; this is the direct consequence of the late winter descent that persisted without interruption until early April. By contrast, the highest summer $\mathrm{CH}_{4}$ was in
Table 1. Categorization of summer upper stratospheric $\mathrm{CH}_{4}$.

\begin{tabular}{rlllr}
\hline Category & $\begin{array}{l}\text { Winter } \\
\text { descent }\end{array}$ & $\begin{array}{l}\text { Spring } \\
\text { PW }\end{array}$ & $\begin{array}{l}\mathrm{CH}_{4} \\
\text { value }\end{array}$ & $\begin{array}{r}\text { Representative } \\
\text { year }\end{array}$ \\
\hline 1. & high & low & lowest & 2009 \\
2. & high & high & intermediate & 2013 \\
3. & low & low & intermediate & 2008 \\
4. & low & high & highest & 2011 \\
\hline
\end{tabular}

$\mathrm{PW}$ is planetary wave.

2011 which is the result of the dynamically quiet winter followed by the FrIAC in early April that caused the $\mathrm{CH}_{4}$ to almost double. The other 5 years are intermediate, although as noted above, 2010 and 2012 are close to 2009. For all 7 years, once the relative abundances of $\mathrm{CH}_{4}$ were established by 1 May (day 121), they remained mostly unchanged with respect to each other until October (around day 280). Figure 2b shows WACCM zonal mean $\mathrm{CH}_{4}$ results for $1.47 \mathrm{hPa}$ at the single latitude of $75^{\circ} \mathrm{N}$ for 2009 and 2008. The reason for sampling WACCM at a single latitude is to test whether the slow seasonal drift of the SOFIE occultation pattern from 65 to $82^{\circ}$ might be affecting our comparisons. While there are some differences in absolute abundance between WACCM and SOFIE for the first 30-40 days when late winter conditions still prevailed, after that, in spring and summer, the agreement between WACCM at one latitude and SOFIE over a small range of latitudes is excellent. Thus we can conclude that the latitude variation of the SOFIE occultations can be neglected. This is not surprising since wave activity and latitudinal gradients are relatively weak in summer.

Table 1 presents an idealized categorization of how the summer level of Arctic upper stratospheric $\mathrm{CH}_{4}$ can be placed in the context of the four categories of wintertime descent and early spring dynamical variability. The years 2008 , 2009, 2011 and 2013 are most representative of these idealized cases. The other years are more intermediate; as noted above, 2010 and 2012 were closer to 2009 in having relatively strong late winter descent of mesospheric air and a relative absence of springtime wave activity (with its associated horizontal transport of low-latitude air to polar latitudes; cf. Siskind et al., 2015a). The year 2014 is closer to 2011. As seen in Fig. 2, there was a $50 \%$ increase in $\mathrm{CH}_{4}$ in late March 2014 and we have previously, tentatively suggested that there was a FrIAC event in that spring (Siskind et al., 2015a). Certainly this categorization is qualitative, not quantitative; however, we suggest that it provides a useful framework for analyzing the spring and summer $\mathrm{CH}_{4}$ variability.

\subsection{Chlorine monoxide (ClO)}

Here we explore the chemical consequences of the $\mathrm{CH}_{4}$ variations illustrated above. $\mathrm{CH}_{4}$ has long been known to play an important role in partitioning stratospheric chlo- 

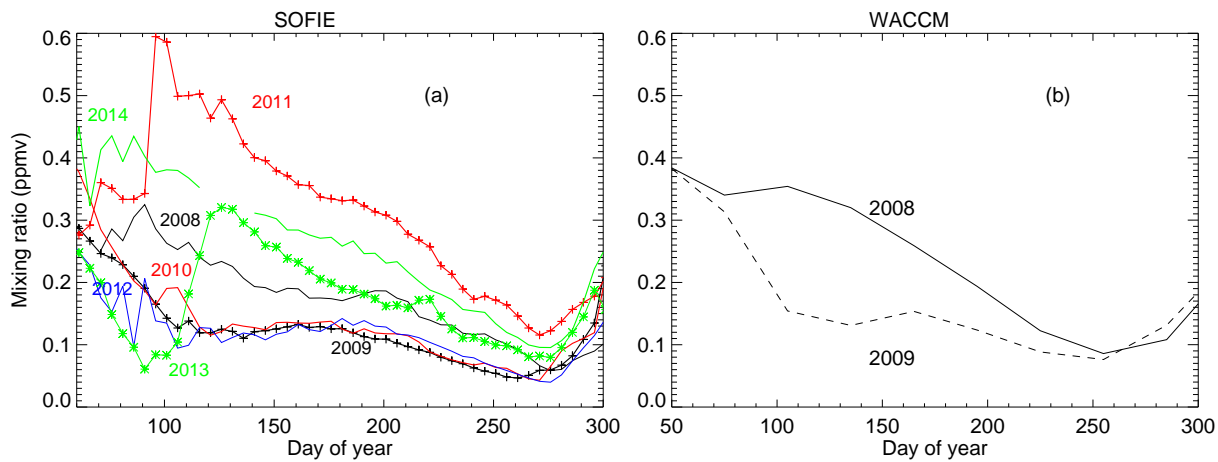

Figure 2. Comparison of time series of zonal mean $\mathrm{CH}_{4}$ mixing ratio at $1.47 \mathrm{hPa}$. (a) SOFIE data for the indicated years. The data have been grouped into 5-day bins. See Fig. 1 for a discussion of the latitudes. (b) WACCM for 2008 (solid) and 2009 (dashed) at a single fixed latitude of $75^{\circ} \mathrm{N}$.

rine (Solomon and Garcia, 1984). Specifically, the reaction $\mathrm{Cl}+\mathrm{CH}_{4} \rightarrow \mathrm{HCl}+\mathrm{CH}_{3}$ means that active chlorine $\left(\mathrm{ClO}_{x}=\right.$ $\mathrm{Cl}+\mathrm{ClO}$ ) should vary inversely with $\mathrm{CH}_{4}$. For example, Siskind et al. (1998) documented an increase in upper stratospheric $\mathrm{ClO}$ during the early years of the Upper Atmospheric Research Satellite (UARS) mission which was explained as a direct consequence of the decrease in $\mathrm{CH}_{4}$ observed by Nedoluha et al. (1998). Froidevaux et al. (2000) observed a general anticorrelation between variations in $\mathrm{ClO}$ and $\mathrm{CH}_{4}$ at $2 \mathrm{hPa}$ in the tropics. They showed that there should be an inverse relationship between $\mathrm{ClO}$ and $\mathrm{CH}_{4}$.

Figure 3 shows that this anticorrelation also exists between high-latitude $\mathrm{CH}_{4}$ and $\mathrm{ClO}$ at $1.47 \mathrm{hPa}$ during the spring and summer. It plots monthly averaged $\mathrm{SOFIE} \mathrm{CH}_{4}$ against MLS $\mathrm{ClO}$ (sampled at the SOFIE occultation latitudes) for the period May-August. Although there are only seven datapoints for each month (6 in May due to missing data in 2014), the linear correlation coefficients of -0.92 to -0.97 are highly statistically significant. Note there is a general increase in $\mathrm{ClO}$ from late spring to late summer. This is consistent with the seasonal decrease in $\mathrm{CH}_{4}$ and was discussed by Considine et al. (1998). Concerning the year to year variability, the highest summertime $\mathrm{ClO}$ for the 7-year period is in 2009. This is a legacy of the strong uninterrupted descent which followed the January 2009 SSW. Other years with relatively high $\mathrm{ClO}$ include 2010 and 2012 which, as we have discussed, were also years similar to 2009 in their combination of winter descent and spring planetary waves. The lowest summertime $\mathrm{ClO}$ is in 2011. This is the result of the strong FrIAC event which occurred in April 2011. The general range of summer $\mathrm{ClO}$ which stems from the above winter/spring dynamical variability is about $50 \%$.

Figure 3 also gives the slopes $(m)$ of the linear fit between $\mathrm{ClO}$ and $\mathrm{CH}_{4}$. It shows a tendency for progressively steeper (more negative) slopes as the summer progresses and methane decreases. In general, all the values of $m$ are more negative than the value $\left(-0.42 \mathrm{ppbv} \mathrm{ppmv}^{-1}\right)$ quoted by Nedoluha et al. (2011) for tropical conditions. However,
Nedoluha et al. (2011) make the point that the $\mathrm{CH}_{4}$ is relatively high in the tropics (about $0.6 \mathrm{ppmv}$ according to their Fig. 7). Thus the pattern of steeper slopes for lower $\mathrm{CH}_{4}$ is robust across both Nedoluha et al's and our analyses. This is precisely the pattern one would expect for the inverse power relationships discussed by Froidevaux et al. (2000). Thus the present SOFIE/MLS comparison is consistent with studies using both UARS and ground-based data that showed $\mathrm{ClO}$ and $\mathrm{CH}_{4}$ in the upper stratosphere varying with a high degree of anticorrelation.

To get a broader picture of the $\mathrm{ClO}$ and $\mathrm{CH}_{4}$ changes at latitudes other than the narrow range sampled by SOFIE, Fig. 4 shows the monthly average zonal mean WACCM/NOGAPS $\mathrm{ClO}$ and $\mathrm{CH}_{4}$ difference fields for August 2009 minus August 2008. Profiles that are compared with MLS (for ClO) and SOFIE (for $\mathrm{CH}_{4}$ ) for the SOFIE occultation latitude (given by the dashed white line in the color panel) are also shown in the right-hand plots. The comparison between the model and the data is excellent. Since the difference between 2009 and 2008 represents about half the difference between the extreme years discussed above (2009 and 2011), one can multiply the $\mathrm{ClO}$ and $\mathrm{CH}_{4}$ difference values in Fig. 4 by a factor of 2 to get an estimate of the full range. The model shows that the low $2009 \mathrm{CH}_{4}$ and high $2009 \mathrm{ClO}$ shown in Fig. 4 are part of a broad region of perturbation extending from 40 to $50^{\circ} \mathrm{N}$ to the pole and covering the altitude region between about 1 and $8 \mathrm{hPa}$. There may be a small vertical offset, perhaps one grid point, whereby the model profile is shifted slightly downward relative to both the MLS and SOFIE data. A similar offset was recently noted by (Siskind et al., 2015b) in their WACCM/NOGAPS simulation of the 2009 descent of mesospheric $\mathrm{NO}_{x}$. Since the summer $\mathrm{CH}_{4}$ depletion is a consequence of the winter descent, this offset may reflect the small discrepancy seen by Siskind et al. (2015b).

Figure 4 shows that the effect of the $\mathrm{CH}_{4}$ on $\mathrm{ClO}$ occurs over a relatively deep layer in the upper stratosphere; the detailed plots of the time behavior of $\mathrm{CH}_{4}$ and $\mathrm{ClO}$, specifi- 


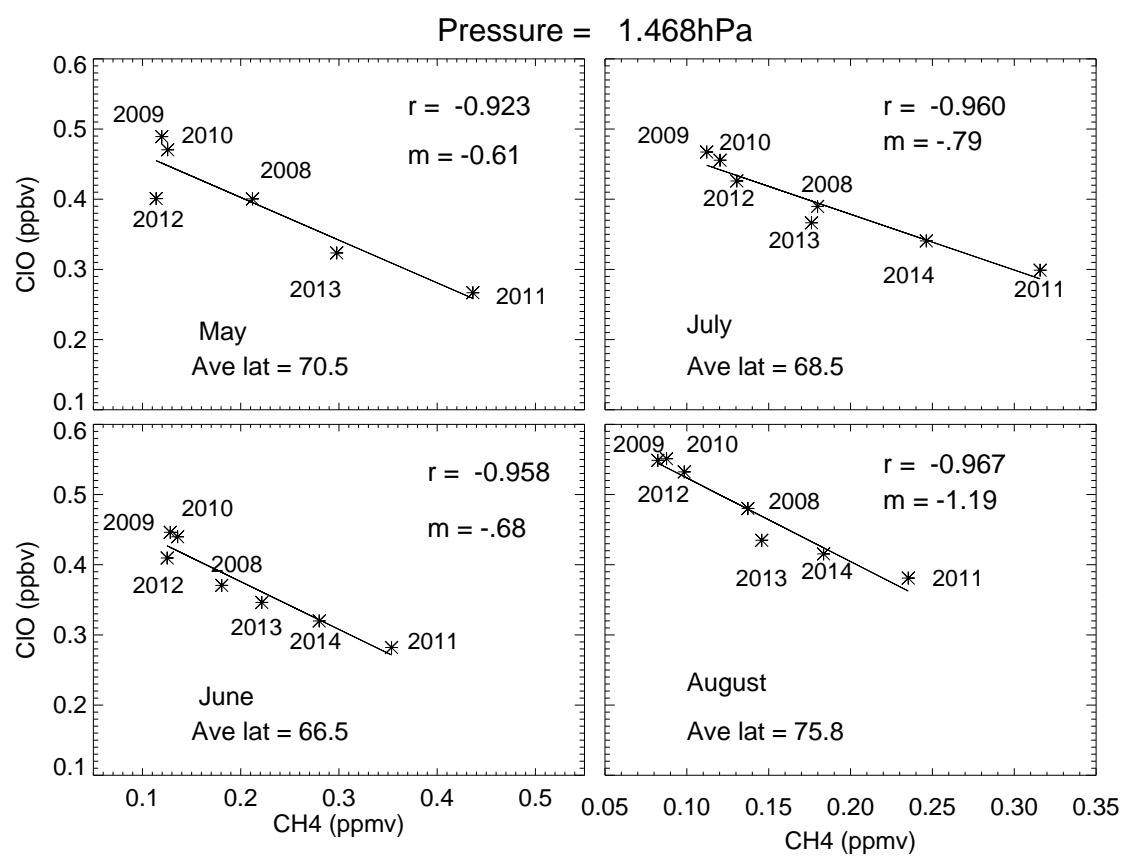

Figure 3. Scatter plot of zonal mean, monthly averaged MLS ClO vs. SOFIE $\mathrm{CH}_{4}$ at $1.47 \mathrm{hPa}$. The MLS data are sampled at the SOFIE occultation latitude, the monthly averages of which are indicated in each panel. In the upper right of each panel the linear correlation coefficients $(r)$ between each dataset for each month are given, as well as the slope of the linear fit $(m)$ in units of ppbv of ClO per ppmv of $\mathrm{CH}_{4}$.

cally Figs. 2 and 3, represent only the uppermost edge of this larger perturbation. The reason for focusing on this narrower region is that these altitudes, between 1 and $3 \mathrm{hPa}$, are where the chlorine cycle is affecting the ozone. This is discussed in the next section.

\subsection{Ozone $\left(\mathrm{O}_{3}\right)$}

Figure 5 presents a time series of upper stratospheric ozone from MLS in a format similar to Fig. 2 for $\mathrm{CH}_{4}$. Only 4 years are shown because in summer, the curves almost overlap and it would be hard to distinguish all 7 years clearly. The 4 years shown correspond to the representative years given in Table 1. The figure shows very large variability in March and April, both intra- and interannually. This is largely driven by the large temperature variability, which itself is dynamically driven, as discussed by several authors (Siskind et al., 2015a; McCormack et al., 2006; Smith, 1995; Froidevaux et al., 1989). Of interest here is that after 1 May the interannual variability becomes very small, but is not zero. It also shows that the relative abundance from year to year remains generally fixed throughout the summer into the autumn. This small remaining difference is due to chlorine chemistry, as seen below.

Figure 6 shows the zonal and monthly averaged odd oxygen loss rates from the $\mathrm{HO}_{x}, \mathrm{ClO}_{x}$ and $\mathrm{NO}_{x}$ catalytic cycles for June 2008 and 2009 at $75^{\circ} \mathrm{N}$ calculated by WACCM/NOGAPS. The expressions for these terms are from Eq. (A1) of McCormack et al. (2006). The figure shows that the contribution to total odd oxygen loss from chlorine chemistry maximizes in a narrow layer from 1 to $3 \mathrm{hPa}$ and that it is greater in 2009 than in 2008. This is consistent with the greater $\mathrm{ClO}$ observed by MLS in 2009 as shown in Fig. 3. The $\mathrm{HO}_{x}$ cycle shows little change, but the $\mathrm{NO}_{x}$ cycle actually shows the opposite effect, i.e., decreased loss in 2009. This is perhaps surprising and is worth documenting. Figure 7 shows the monthly averaged $\mathrm{NO}_{x}$ (i.e., $\mathrm{NO}+$ $\mathrm{NO}_{2}$ ) from WACCM for June for $75^{\circ} \mathrm{N}$ for 2009 and 2008. Above the stratosphere, from 1 to $0.1 \mathrm{hPa}, \mathrm{NO}_{x}$ was higher in 2009. This is likely a legacy of enhanced descent from the upper mesosphere observed earlier that spring. However, as discussed by Siskind et al. (2015b) and also by Salmi et al. (2011) in their study of data from the Atmospheric Chemistry Experiment Fourier Transform Spectrometer, there is no evidence that these enhancements penetrated down to altitudes where the $\mathrm{NO}_{x}$ catalytic cycle affects ozone. Although SOFIE does not measure $\mathrm{NO}_{2}$, the excellent agreement between WACCM NO and SOFIE NO documented by Siskind et al. (2015b) gives us confidence that the $\mathrm{WACCM} \mathrm{NO}_{x}$ results are an accurate reflection of reality. We suggest that the lower $\mathrm{NO}_{x}$ from 1 to $8 \mathrm{hPa}$ in 2009 is a legacy of greater winter/spring descent from the region of the NO minimum in the mesosphere near $60-75 \mathrm{~km}$.

Thus while there is some offsetting of the changes in the chlorine cycle by the lower $2009 \mathrm{NO}_{x}$, the net effect is that in the $1-2 \mathrm{hPa}$ layer, the overall odd oxygen loss is greater in 

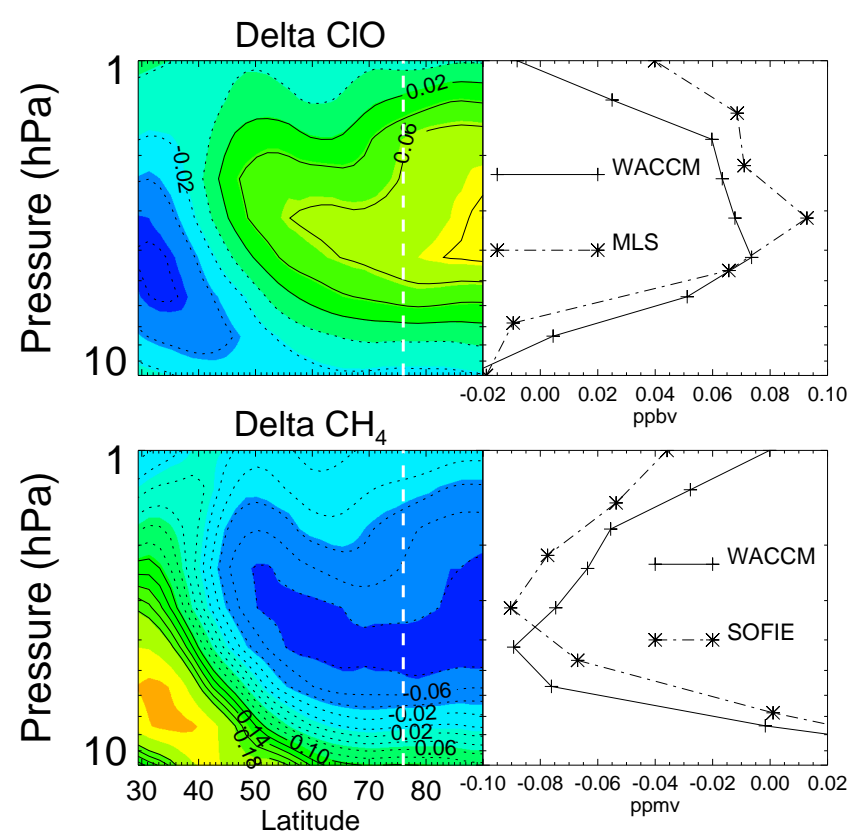

Figure 4. The color contours on the left are zonal mean WACCM/NOGAPS difference fields for August 2009 minus August 2008 for $\mathrm{ClO}$ (top) and $\mathrm{CH}_{4}$ (bottom). The vertical dashed white line is the mean latitude of the SOFIE occultations for August. On the right, a vertical profile of the model difference at the SOFIE occultation latitude (solid line with plus symbols) is compared with MLS $\mathrm{ClO}$ and SOFIE $\mathrm{CH}_{4}$ (data are dotted/dashed curves with stars). Note that $x$ axes for the right panels are reversed from one another since the $\mathrm{ClO}$ change is positive, while the $\mathrm{CH}_{4}$ change is negative.

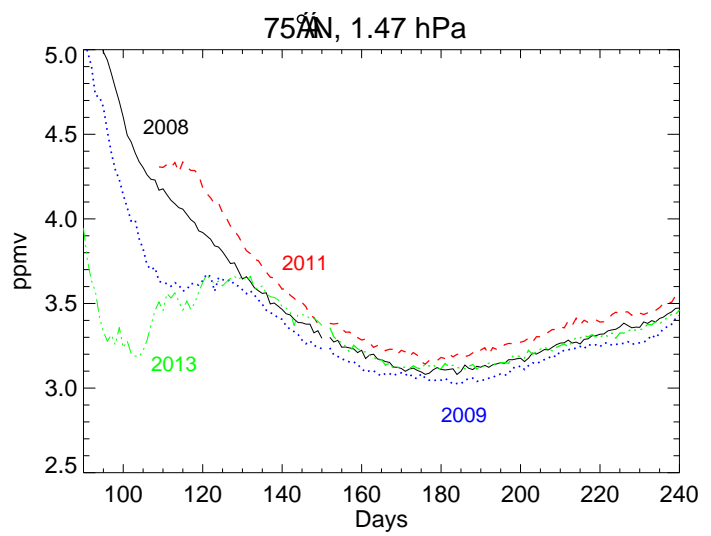

Figure 5. Time series of zonally averaged ozone from MLS at $75^{\circ} \mathrm{N}$.

2009. Between 3 and $7 \mathrm{hPa}$, it is less in 2009. These changes agree well with observed ozone changes, as seen by MLS. This is shown in Fig. 8 which presents an altitude profile of the ozone change from WACCM/NOGAPS compared with MLS for June at $75^{\circ} \mathrm{N}$. The figure shows the relative 2009 ozone decrease near $1-2 \mathrm{hPa}$, corresponding to the increase

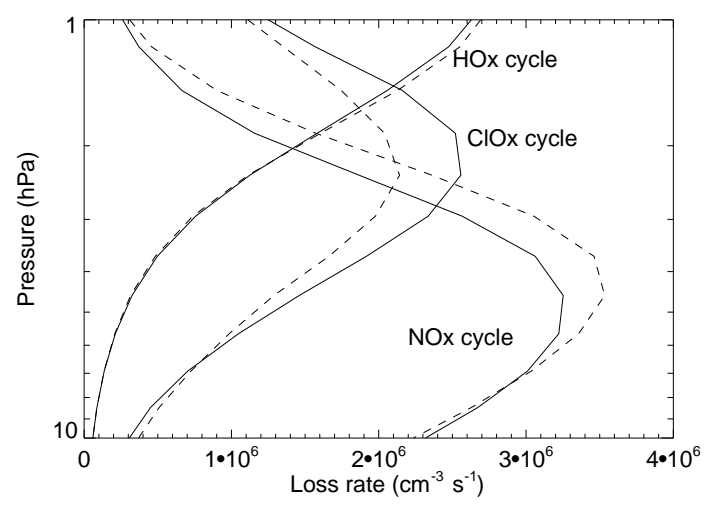

Figure 6. Altitude profiles of monthly and daily averaged ozone loss rates from WACCM/NOGAPS for June 2009 (solid) and June 2008 (dashed) at $75^{\circ} \mathrm{N}$.

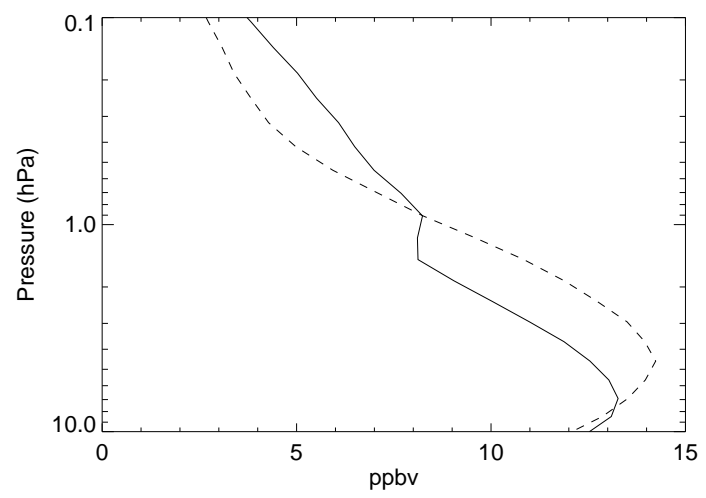

Figure 7. Monthly averaged WACCM/NOGAPS $\mathrm{NO}_{x}(=\mathrm{NO}+$ $\mathrm{NO}_{2}$ for June 2009 (solid) and 2008 (dashed) at $75^{\circ} \mathrm{N}$.

in chlorine loss. From 4 to $6 \mathrm{hPa}$, there is a small ozone increase in 2009 which corresponds to the small reduction in $\mathrm{NO}_{x}$ loss suggested by Figs. 6 and 7.

Figure 9 shows that the ozone change over the entire 7 year period is consistent with the above analysis for 2008 and 2009. Figure 9 presents monthly averaged correlation coefficients between MLS ozone and MLS ClO (Fig. 8a) and between MLS ozone and SOFIE $\mathrm{CH}_{4}$ (Fig. 8b) for $1.47 \mathrm{hPa}$. Figure $9 \mathrm{a}$ shows that the approximate $5 \%$ spread in ozone values is almost perfectly anticorrelated with the $50 \% \mathrm{ClO}$ changes shown in Fig. 3. Further, since we have previously shown that the summer $\mathrm{ClO}$ in the upper stratosphere reflects the interannual variability in $\mathrm{CH}_{4}$, it is no surprise that MLS $\mathrm{O}_{3}$, sampled at SOFIE latitudes, should almost perfectly correlate with SOFIE $\mathrm{CH}_{4}$. This is shown in Fig. 9b.

Finally, Fig. 10 plots the linear correlation coefficient of $\mathrm{CH}_{4}$ and $\mathrm{O}_{3}$ as a function of altitude. Four curves are shown, corresponding to the four monthly averages presented in Fig. 5. The figure shows that the correlation maximizes in the $1-2 \mathrm{hPa}$ region with values near and above 0.9 . This is to be expected from the chlorine cycle as shown in Fig. 6 above. Below 2-3hPa, the $\mathrm{NO}_{x}$ cycle becomes more domi- 


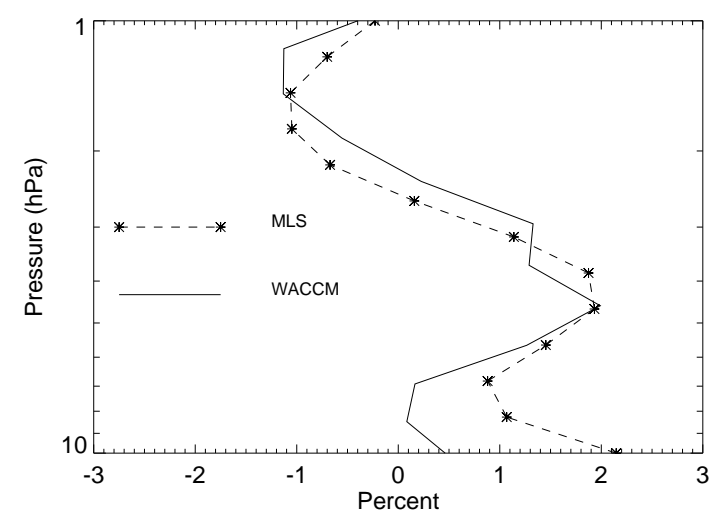

Figure 8. Percent change in monthly averaged ozone for June 2009 minus June 2008 at $75^{\circ} \mathrm{N}$. The solid line is from WACCM/NOGAPS and the dashed line with stars is from MLS data.
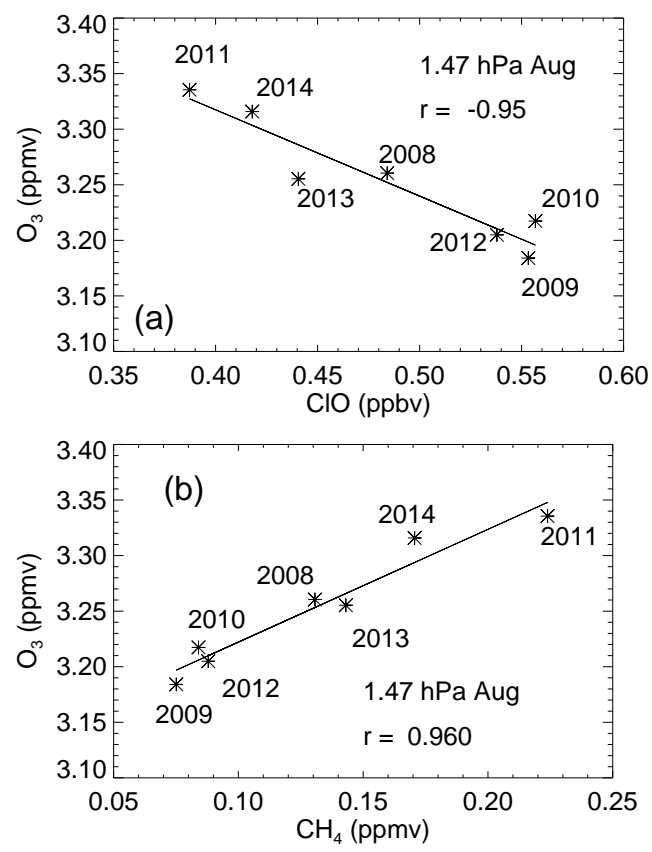

Figure 9. Scatter plot of August monthly mean MLS $\mathrm{O}_{3}$ vs. (a) MLS $\mathrm{ClO}$ and (b) SOFIE $\mathrm{CH}_{4}$ at $1.47 \mathrm{hPa}$. The latitudes are near $78^{\circ} \mathrm{N}$, corresponding to the latitude of the SOFIE occultations in August.

nant and the link to $\mathrm{CH}_{4}$ disappears. Thus the effects of uninterrupted wintertime descent of mesospheric air on ozone may fall into two categories, separated by altitude. From 1 to $2 \mathrm{hPa}$ the ozone reductions result from chlorine enhancements; for higher pressures, the potential for $\mathrm{NO}_{x}$ enhancements dominates, provided such enhancements were to make it down to those pressures.

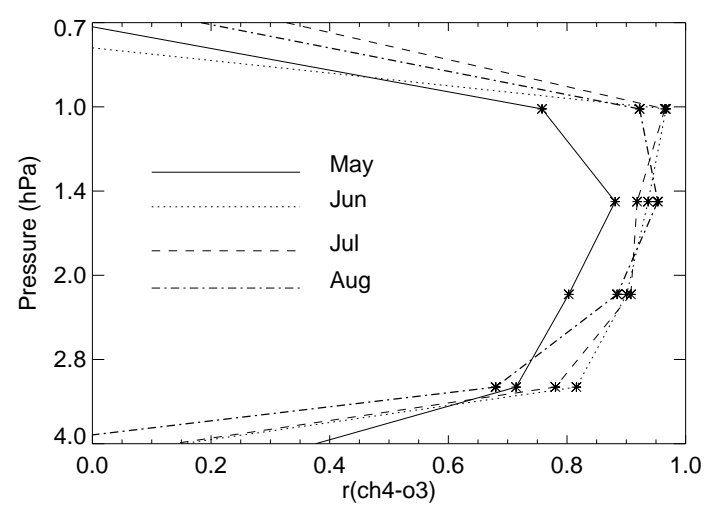

Figure 10. Altitude profiles of linear correlation coefficients for SOFIE $\mathrm{CH}_{4}$ and $\mathrm{MLS} \mathrm{O}_{3}$ (sampled at the SOFIE occultation latitudes). The four curves are taken from zonal mean averages for May (solid), June (long dashes), July (dotted) and August (dotted/dashed).

\section{Conclusions}

We have shown how the chemical composition in the summertime upper stratosphere depends upon dynamical activity from the previous winter and spring. Our main result is to identify a new mechanism for summertime $\mathrm{ClO}$ and $\mathrm{O}_{3}$ variability, namely due to $\mathrm{CH}_{4}$ variations which, in turn, depend upon both the magnitude of wintertime mesospheric descent and springtime planetary waves. In 2009, prolonged mesospheric descent and a relative absence of springtime wave activity lead to relatively low values of $\mathrm{CH}_{4}$ which persisted throughout the summer. At the other extreme, in 2011, the lack of strong winter descent combined with an intense frozen-in anticyclone event in early April led to $\mathrm{CH}_{4}$ values which were more than twice that in 2009.

The excellent anticorrelation between MLS $\mathrm{ClO}$ and SOFIE $\mathrm{CH}_{4}$ both validates our understanding of reactive chlorine partitioning and also offers a framework for interpreting future observations. Due to orbital precession, the latitudes of the SOFIE occultations have drifted away from polar region and SOFIE is presently unable to monitor wintertime tracer descent. However, based upon the results in this paper, perhaps MLS ClO data can be used as a proxy for this. It would also be interesting to consider whether these variations in $\mathrm{ClO}$ have any impact on $\mathrm{O}_{3}$ trend assessments. Both the strong winter descent and the spring FrIAC phenomenon seem to be more common in recent years (Allen et al., 2011; Manney et al., 2005). In principle, the enhanced variability we have shown here might have to be considered, at least for trend studies at high latitudes. Recent estimates of $\mathrm{ClO}$ trends (Jones et al., 2011) have only considered the tropics.

Our work shows that these $\mathrm{CH}_{4}$ and $\mathrm{ClO}$ variations have caused up to a $5 \%$ variation in upper stratospheric ozone throughout the summer and early fall. This confirms the gen- 
eral role of chlorine chemistry in upper stratospheric ozone. This also represents a second mechanism, in addition to that associated with a descent of enhanced mesospheric $\mathrm{NO}_{x}$, by which descent of mesospheric air can cause ozone reductions. Studies of spring- and summertime ozone loss following strong descent years should take care to distinguish between these two mechanisms. One way to distinguish them may be according to altitude. Thus ozone decreases for $p<3 \mathrm{hPa}(z>40 \mathrm{~km})$ are more likely the result of low $\mathrm{CH}_{4}$, whereas for $p>3 \mathrm{hPa}(z<40 \mathrm{~km}), \mathrm{NO}_{x}$ enhancements would dominate. A likely example of this second case is shown in Fig. 1 of Randall et al. (2005).

Finally, the question of whether this variability would influence trend analyses may be worth considering. There was earlier work using Upper Atmospheric Research Satellite data to look at hemispheric differences in ozone trends (Considine et al., 1998); in light of the more recent dynamical variability seen in the $\mathrm{NH}$, and its now documented impact on ozone, perhaps this should be revisited.

\section{Data availability}

SOFIE data are available on line at http://sofie.gats-inc. com. MLS data are available from the NASA Goddard Earth Science Data Information and Services Center (http: //acdisc.gsfc.nasa.gov). The WACCM model and instructions for its use are available at https://www2.cesm.ucar.edu/ working-groups/wawg.

Acknowledgements. We acknowledge the Aeronomy of Ice in the Mesosphere explorer program from the NASA Small Explorer Program. Two of us (Fabrizio Sassi and Gerald E. Nedoluha) additionally acknowledge funding from the Chief of Naval Research.

Edited by: F. Khosrawi

\section{References}

Allen, D. R., Douglass, A. R., Manney, G. L., Strahan, S. E., Krosschell, J. C., Trueblood, J. V., Nielsen, J. E., Pawson, S., and Zhu, Z.: Modeling the Frozen-In Anticyclone in the 2005 Arctic Summer Stratosphere, Atmos. Chem. Phys., 11, 4557-4576, doi:10.5194/acp-11-4557-2011, 2011.

Andrews, D. G., Holton, J. R., and Leovy, C. B.: Middle Atmosphere Dynamics, Academic Press, 489 pp., 1987.

Bailey, S. M., Thurairajah, B., Randall, C. E., Holt, L., Siskind, D. E., Harvey, V. L., Venkataramani, K., Hervig, M. E., Rong, P., and Russell III, J. M.: A multi tracer analysis of thermosphere to stratosphere descent triggered by the 2013 Stratospheric Sudden Warming, Geophys. Res. Lett., 41, 5216-5222, doi:10.1002/2014GL059860, 2014.

Chandran, A., Collins, R. L., Garcia, R. R., Marsh, D. R., Harvey, V. L., Yue, J., and de la Torre, L.: A climatology of elevated stratopause events in the whole atmosphere community climate model, J. Geophys. Res., 118, 1-13, doi:10.1002/jgrd.50123, 2013.

Considine, D., Dessler, A. E., Jackman, C. H., Roesnfield, J. E., Meade, P. E., Schoeberl, M. R., Roche, A. E., and Waters, J. W.: Interhemispheric asymmetry in the 1 mbar $\mathrm{O}_{3}$ trend: An analysis using an interactive zonal mean model and UARS data, J. Geophys. Res., 103, 1607-1618, 1998.

Eckermann, S. D., Hoppel, K. W., Coy, L., McCormack, J. P., Siskind, D. E., Nielsen, K., Kochenash, A., Stevens, M. H., Englert, C. R., Singer, W., and Hervig, M.: High altitude data assimilation experiments for the Northern Hemisphere summer mesosphere season of 2007, J. Atmos. Sol.-Terr Phys., 71, 531-551, 2009.

Fiedler, J., Baumgarten, G., Berger, U., Gabriel, A., Latteck, R., and Lubken, F.-J.: On the early onset of the NLC season as observed at Alomar, J. Atmos. Sol.-Terr. Phys., 127, 73-77, doi:10.1016/j.jastp.2014.07.011, 2015.

Froidevaux, L., Allen, M., Berman, S., and Daughton, A.: The mean ozone profile and its temperature sensitivity in the upper stratosphere and mesosphere: an analysis of LIMS observations, J. Geophys. Res., 94, 6389-6417, 1989.

Froidevaux, L., Waters, J. W., Read, W. G., Connell, P. S., Kinnison, D. E., and Russell III, J. M.: Variations in the free chlorine content of the stratosphere (1991-1997): Anthropogenic, volcanic and methane influences, J. Geophys. Res., 105, 4471-4481, 2000.

Froidevaux, L., Jiang, Y. B., Lambert, A., Livesey, N. J., Read, W. G., Waters, J. W., Browell, E. V., Hair, J. W., Avery, M. A., McGee, T. J., Twigg, L. W., Sumnicht, G. K., Jucks, K. W., Margitan, J. J., Sen, B., Stachnik, R. A., Toon, G. C., Bernath, P. F., Boone, C. D., Walker, K. A., Filipiak, M. J., Harwood, R. S., Fuller, R. A., Manney, G. L., Schwartz, M. J., Daffer, W. H., Drouin, B. J., Cofield, R. E., Cuddy, D. T., Jarnot, R. F., Knosp, B. W., Perun, V. S., Snyder, W. V., Stek, P. C., Thurstans, R. P., and Wagner, P. A.: Validation of Aura Microwave Limb Sounder stratospheric ozone measurements, J. Geophys. Res., 113, D15S20, doi:10.1029/2007JD008771, 2008.

Funke, B., Lopez-Puertas, M., Stiller, G. P., and von Clarmann, T.: Mesospheric and stratospheric $\mathrm{NO}_{y}$ produced by energetic particle precipitation during 2002-2012, J. Geophys. Res.,, 119, 4429-4446, 2014.

Garcia, R. R., Marsh, D. R., Kinnison, D. E., Boville, B. A., and Sassi, F.: Simulation of secular trends in the middle atmosphere, J. Geophys. Res., 112, D09301, doi:10.1029/2006JD007485, 2007.

Gordley, L. L., Hervig, M. E., Fish, C., Russell III, J. M., Bailey, S. M., Cook, J., Hansen, S., Shumway, A., Paxton, G., Deaver, L., Marshall, T., Burton, J., Magill, B., Brown, C., Thompson, E., and Kemp, J.: The solar occultation for ice experiment, J. Atmos. Sol.-Terr Phys., 71, 300-315, 2009.

Hess, P.: Variance in trace constituents following the final stratospheric warming, J. Geophys. Res., 95, 13765-13779, 1990.

$\mathrm{Hu}, \mathrm{J} ., \mathrm{Ren}, \mathrm{R}$., and $\mathrm{Xu}, \mathrm{H} .:$ Occurrence of winter stratospheric sudden warming events and the seasonal timing of spring stratospheric final warming, J. Atmos. Sci, 71, 2139-2334, doi:10.1175/JAS-D-13-0349.1, 2014.

Jones, A., Urban, J., Murtagh, D. P., Sanchez, C., Walker, K. A., Livesey, N. J., Froidevaux, L., and Santee, M. L.: Analysis of $\mathrm{HCl}$ and $\mathrm{ClO}$ time series in the upper stratosphere using satellite 
data sets, Atmos. Chem. Phys., 11, 5321-5333, doi:10.5194/acp11-5321-2011, 2011.

Lahoz, W. A., Geer, A. J., and Orsolini, Y. J.: Northern Hemisphere stratospehre summer from MIPAS observations, Q. J. Roy. Meteor. Soc., 133,197-211, 2007.

Letexier, H., Solomon, S., and Garcia, R. R.: The role of molecular hydrogen and methane oxidation in the water vapour budget of the stratosphere, Q. J. Roy. Meteor. Soc., 114, 281-295, 1988.

Manney, G. L., Kruger, K., Sabutis, J. L., Sena, S. A., and Pawson, S.: The remarkable 2003-04 winter and other recent warm winters in the Arctic stratosphere since the late 1990s, J. Geophys. Res., 110, D04107, doi:10.1029/2004JD005367, 2005.

Manney, G. L., Livesey, N. J., Jimenez, C. J., Pumphrey, H. C., Santee, M. L., MacKenzie, I. A., and Waters, J. W.: EOS Microwave Limb Sounder observations of frozen-in anticyclonic air in arctic summer, Geophys. Res. Lett., 33, L08610, doi:10.1029/2005GL025418, 2006.

Manney, G. L., Krüger, K., Pawson, S., Minschwaner, K., Schwartz, M. J., Daffer, W. H., Livesey, N. J., Mlynczak, M. G., Remsberg, E. E., Russell III, J. M., and Waters, J. W.: The evolution of the stratopause during the 2006 major warming: Satellite data and assimilated meteorological analyses, J. Geophys. Res., 113, D11115, doi:10.1029/2007JD009097, 2008a.

Manney, G. L., Daffer, W. H., Strawbridge, K. B., Walker, K. A., Boone, C. D., Bernath, P. F., Kerzenmacher, T., Schwartz, M. J., Strong, K., Sica, R. J., Krüger, K., Pumphrey, H. C., Lambert, A., Santee, M. L., Livesey, N. J., Remsberg, E. E., Mlynczak, M. G., and Russell III, J. R.: The high Arctic in extreme winters: vortex, temperature, and MLS and ACE-FTS trace gas evolution, Atmos. Chem. Phys., 8, 505-522, doi:10.5194/acp-8-505-2008, 2008 b.

Manney, G. L., Schwartz, M. J., Kruger, K., Santee, M. L., Pawson, S., Lee, J. N., Daffer, W. H., Fuller, R. A., and Livesey, N. J.: Aura Microwave Limb Sounder observations of dynamics and transport during the record-breaking 2009 Arctic stratospheric major warming, Geophys. Res. Lett., 36, L12815, doi:10.1029/2009GL038586, 2009.

Manney, G. L., Santee, M. L., Rex, M., Livesey, N. J., Pitts, M. C., Veefkind, P., Nash, E. R., Wohltmann, I., Lehmann, R., Froidevaux, L., Poole, L. R., Schoeberl, M. R., Haffner, D. P., Davies, J., Dorokhov, V., Gernandt, H., Johnson, B., Kivi, R., Kyrö, E., Larsen, N., Levelt, P. F., Makshtas, A., McElroy, C. T., Nakajima, H., Parrondo, M. C., Tarasick, D. W., von der Gathen, P., Walker, K. A., and Zinoviev, N. S.: Unpredecented Arctic ozone loss in 2011, Nature, 478, p. 69, 2011.

Marsh, D. R.: Chemical dynamical coupling in the mesosphere and lower thermosphere, Aeronomy of the Earth's Atmosphere and Ionosphere (IAGA, Special Sopron Book Series 2), 2011.

McCormack, J. P., Eckermann, S. D., Siskind, D. E., and McGee, T. J.: CHEM2D-OPP: A new linearized gas-phase ozone photochemistry parameterization for high-altitude NWP and climate models, Atmos. Chem. Phys., 6, 4943-4972, doi:10.5194/acp-64943-2006, 2006.

Nedoluha, G. E., Siskind, D. E., Bacmeister, J. T., and Bevilacqua, R. M.: Changes in upper stratospheric $\mathrm{CH}_{4}$ and $\mathrm{NO}_{2}$ as measured by HALOE and implications for changes in transport, Geophys. Res. Lett., 25, 987-990, 1998.

Nedoluha, G. E., Connor, B. J., Barrett, J., Mooney, T., Parrish, A., Boyd, I., Wrotny, J. E., Gomez, R. M., Koda, J., Santee, M. L., and Froidevaux, L.: Ground based measurements of $\mathrm{ClO}$ from
Mauna Kea and intercomparisons with Aura and UARS MLS, J. Geophys. Res., 116, D02307, doi:10.1029/2010JD014732, 2011.

Orsolini, Y. J.: Long lived tracer patterns in the summer polar stratosphere, Geophys. Res. Lett., 28, 3855-3858, 2001.

Randall, C. E., Harvey, V. L., Manney, G. L., Orsolini, Y., Codrescu, M., Sioris, C., Brohede, S., Haley, C. S., Gordley, L. L., and Zawodny, J. M.: Stratospheric effects of energetic particle precipitation in 2003-2004, Geophys. Res. Lett., 32, L05802, doi:10.1029/2004GL022003, 2005

Randall, C. E., Harvey, V. L., Siskind, D. E., France, J., Bernath, P. F., Boone, C. D., and Walker, K. A.: $\mathrm{NO}_{x}$ descent in the Arctic middle atmosphere in early 2009, Geophys. Res. Lett., 36, L18811, doi:10.1029/2009GL039706, 2009.

Randall, C. E., Harvey, V. L., Holt, L. A., Marsh, D. R., Kinnison, D., Funke, B., and Bernath, P. F.: Simulation of energetic particle precipitation effects during the 2003-2004 Arctic winter, J. Geophys. Res., 120, 5035-5048, doi:10.1002/2015JA021196, 2015.

Rong, P., Russell III, J. M., Marshall, B. T., Siskind, D. E., Hervig, M. E., Gordley, L. L., Bernath, P. F., and Walker, K. A.: Version 1.3 AIM SOFIE measured methane $\left(\mathrm{CH}_{4}\right)$ : Validation and Climatology, J. Geophys. Res., submitted, 2016.

Russell III, J. M., Bailey, S. M., Gordley, L. L., Rusch, D. W., Horanyi, M., Hervig, M. E., Thomas, G. E., Randall, C. E., Siskind, D. E., Stevens, M. H., Summers, M. E., Taylor, M. J., Englert, C. R., Espy, P. J., McClintock, W. E., and Merkel, A. W.: Aeronomy of ice in the Mesosphere (AIM): Overview and early science results, J. Atmos. Sol. Terr. Phys. 71, 289-299, doi:10.1016/j.jastp.2008.08.011, 2009.

Salmi, S.-M., Verronen, P. T., Thölix, L., Kyrölä, E., Backman, L., Karpechko, A. Yu., and Seppälä, A.: Mesosphere-to-stratosphere descent of odd nitrogen in February-March 2009 after sudden stratospheric warming, Atmos. Chem. Phys., 11, 4645-4655, doi:10.5194/acp-11-4645-2011, 2011.

Santee, M. L., Lambert, A., Read, W. G., Livesey, N. J., Manney, G. L., Cofield, R. E., Cuddy, D. T., Daffer, W. H., Drouin, B. J., Froidevaux, L., Fuller, R. A., Jarnot, R. F., Knosp, B. W., Perun, V. S., Snyder, W. V., Stek, P. C., Thurstans, R. P., Wagner, P. A., Waters, J. W., Connor, B., Urban, J., Murtagh, D., Ricaud, P., Barret, B., Kleinböhl, A., Kuttippurath, J., Küllmann, H., von Hobe, M., Toon, G. C., and Stachnik, R. A.: Validation of the Aura Microwave Limb Sounder ClO measurements, J. Geophys. Res., 113, D15S22, doi:10.1029/2007JD008762, 2008.

Sassi, F., Liu, H.-L., Ma, J., and Garcia, R. R.: The lower thermosphere during the northern winter of 2009: a modeling study using high-altitude data assimilation products in WACCM-X, J. Geophys. Res., 118, 8954-8968, doi:/10.1002/jgrd.50632, 2013.

Siskind, D. E., Froidevaux, L., Russell III, J. M., and Lean, J.: Implications of upper stratospheric trace constituent changes observed by HALOE for $\mathrm{O}_{3}$ and $\mathrm{ClO}$ from 1992 to 1995, Geophys. Res. Lett., 25, 3513-3516, 1998.

Siskind, D. E., Eckermann, S. D., Coy, L., McCormack, J. P., and Randall, C. E.: On recent interannual variability of the Arctic winter mesosphere: Implications for tracer descent, Geophys Res. Lett., 34, L09806, doi:10.1029/2007GL029293, 2007.

Siskind, D. E., Eckermann, S. D., McCormack, J. P., Coy, L., Hoppel, K. W., and Baker, N. L.: Case studies of the mesospheric response to minor, major and extended stratospheric warmings, J. Geophys. Res., 115, D00N03, doi:10.1029/2010JD014114, 2010. 
Siskind, D. E., Stevens, M. H., Englert, C. R., and Mlynczak, M. G.: Comparison of a photochemical model with observations of mesospheric hydroxyl and ozone, J. Geophys. Res., 118, 195207, doi:10.1029/2012JD017971, 2013.

Siskind, D. E., Allen, D. R., Randall, C. E., Harvey, V. L., Hervig, M. E., Lumpe, J., Thurairajah, B., Bailey, S. M., and Russell III, J. M.: Extreme stratospheric springs and their consequences for the onset of polar mesospheric clouds, J. Atmos. Sol.-Terr. Phys., 132, 74-81, doi:10.1016/j.jastp.2015.06.014, 2015a.

Siskind, D. E., Sassi, F., Randall, C. E., Harvey, V. L., Hervig, M. E., and Bailey, S. M.: Is a high altitude meteorological analysis necessary to simulate thermosphere-stratosphere coupling?, Geophys. Res. Lett., 42, doi:10.1002/2015GL065838, 2015 b.

Smith, A. K.: Numerical simulations of global variations of temperature, ozone, and trace species of the stratosphere, J. Geophys. Res., 100, 1253-1269, 1995.
Solomon, S. and Garcia, R. R.: On the distributions of long-lived tracers and chlorine species in the middle atmosphere, J. Geophys. Res., 89, 11633-11644, 1984.

Straub, C., Tschanz, B., Hocke, K., Kämpfer, N., and Smith, A. K.: Transport of mesospheric $\mathrm{H}_{2} \mathrm{O}$ during and after the stratospheric sudden warming of January 2010: observation and simulation, Atmos. Chem. Phys., 12, 5413-5427, doi:10.5194/acp-12-54132012, 2012.

Thieblemont, R. N., Orsolini, Y. J., Hauchecorne, A., Drouin, M. A., and Huret, N.: A climatology of frozen-in anticyclones in the spring Arctic stratospehre over the period 1960-2011, J. Geophys. Res., 118, D20110, doi:10.1002/2014JD021763, 2013.

Waters, J. W.: The Earth Observing System Microwave Limb Sounder (EOS MLS) on the Aura satellite, IEEE Trans. Geosci. Remote Sens., 44, 1075-1092, 2006. 